\title{
浅谈水利工程施工中导流施工技术的应用
}

\author{
李江维 赵爱平 \\ 湖北挚江水利水电工程有限公司
}

DOI:10.32629/hwr.v3i12.2549

[ 摘 要] 随着我国社会经济的不断发展,对于水利工程项目建设的要求也越来越高,在水利工程施工中,导流技术属于重要技术之一,对于工程 建设质量的提高很有帮助,因此也在近年来受到了人们的关注和重视。基于此,本文主要对导流施工技术在水利工程施工中的应用进行了研究。 [关键词] 水利工程施工; 导流施工技术; 应用

近年来, 我国水利工程事业发展尤为迅速, 在此情况下, 也为导流技术 的广泛应用奠定了良好基础, 据相关调查研究表明, 导流技术的应用情况 将与水利工程建设质量息息相关, 因此在具体实践过程中, 强化对导流技 术的高效合理应用至关重要, 通过这一技术, 能够有效缓解或避免水流对 工程施工造成的巨大冲击, 同时为施工建设创造一个良好环境。

\section{1 导流施工技术概述}

在水利工程施工中, 对于导流技术的应用, 主要目的就是为了对施工 过程中的水流问题进行控制和缓解, 为工程建设提供一个良好的环境, 提 高工程建设质量。从根本上杜绝河流汛期、水流泄漏等问题。在对该技术 进行应用的过程中, 由于所涉及范围较广, 因此在正式施工之前, 相关工作 人员必须要对合适的场地进行选择, 之后结合施工现场情况, 对施工方案 进行合理制定, 以确保施工活动的顺利开展, 最大限度凸显导流施工技术 在水利工程施工中的重要作用和价值。

关于导流技术的特征, 一般归纳为以下几点: 第一, 在水利公路施 工中, 需要根据相关的水能指标、地质情况、地形情况等, 对适合应用 导流技术的坝址和环境进行选择。第二, 在对地理位置进行确定之后, 要制定出完善可行的施工方案。第三, 在正式施工之前, 还要对导流技 术应用过程中的相关因素进行考虑, 具体包括水能指标、建筑分布、生 态环境等等。第四, 随着现代科学技术的不断发展, 还要将各种先进的 技术、机械设备等应用于水利工程施工中, 以此来达到创新和完善工程 的目的 ${ }^{[1]}$ 。

\section{2 导流技术在水利工程施工中的实际应用}

目前, 导流技术在水利工程施工中的应用, 主要包括分段围堰法导流 技术以及全段围堰法导流技术两种, 其中, 在全段围堰法导流技术中, 比较 常见的主要包括涵管导流技术、隧洞导流技术以及明渠导流技术。分段围 堰法导流技术主要包括缺口导流技术、底孔导流技术等。实践过程中, 相 关施工人员需要根据施工现场的具体情况对施工技术进行合理选择, 与此

据管理库进行构建, 这样提升了数据的旅行速度, 并且让数据查询服务得 到更好的完善。

3. 4 数据安全。在大数据技术应用过程中, 数据安全也是其中不可忽视 的一部分内容。对于一些数据的存储上大数据技术本身给予了一个良好的 解决方案, 这样智能电网管理的数据本身的有效性就得到了更好的提升。 在出现数据损坏和丢失的情况下, 大数据技术可以轻易的进行恢复, 并且 提升对于各类数据风险的抵御能力和安全性。并且随着云计算的发展, 大 数据与云计算平台具有良好的相容性, 以云计算为核心的数据处理平台能 够满足更加复杂的操作要求, 同时其容量大、运行稳定、安全性高的特点 能够适应现在对数据处理的需求, 大数据可以为云计算的运行提供指导, 对云计算的资源进行有效的调配。
同时, 还要对施工技术、工程效益以及环境污染等问题进行全面考虑, 这样 才能够为水利工程施工活动的顺利开展提供保障, 同时在确保施工人员安 全的基础上, 最大限度凸显导流技术的应用价值和优势。

2. 1 全段围堰法导流技术

正常情况下, 全段围堰法导流技术在水利工程施工中的应用, 主要是 针对于受到多种因素影响而无法或很难进行分期导流的工程而言, 例如水 流湍急、流向较窄、水流较深等。该技术在应用的过程中, 主要就是借助 全段围堰拦截水流, 从而将泄水建筑物设置在河道的两旁, 起到良好的引 流作用 ${ }^{[2]}$ 。

\subsection{1 明渠导流技术}

该技术一般常用于宽阔的环境之下, 实践过程中, 需要在河岸上对 渠道进行挖掘, 以此为水流的顺畅性提供保障。此外, 在水利工程施工过 程中, 对于河床较窄、地质条件较差、分期导流困难的问题, 也可以对名 渠导流技术进行应用, 通过横向围堰建立的方式, 为水流流畅对接提供 保障。但是要注意的问题是, 在对明渠导流技术进行应用的过程中, 一定 要保证明渠的长度合理, 以免深度挖土。与此同时, 明渠导流技术也可以 在一些破旧的老河道中进行应用, 从而达到节约工程建设成本、提高施 工质量的目标。

2.1.2隧道导流技术

明渠导流技术和隧道导流技术差异明显, 正常情况下, 隧道导流技术 主要是应用于河床狭窄、导流量低、地形崎岖的山区。由于工程施工成本 较高, 实践过程中, 通常会采用基坑淹没的方式实现导流, 这样能够大幅度 降低施工成本 ${ }^{[3]}$ 。

2.1.3涵管导流技术

涵管导游技术一般常见于石坝和土坝施工中, 正常情况下, 可对钢筋 混凝土材料进行应用, 以此为整体施工质量提供保障。但是要注意的问题 是, 必须要强化对钢筋混凝土用量的严格控制, 用量过多过少, 都会对施工

大数据时代的新技术带给企业生产经营新的挑战和机遇, 为了适应现 阶段信息化工作的要求, 企业需要做好相关大数据的分析及挖掘工作, 大 数据处理技术必将成为企业决策者洞察行业竞争态势的望远镜, 成为提升 企业核心竞争力的助推器。

\section{[参考文献]}

[1]黄哲学,曹付元,李俊杰,等.面向大数据的海云数据系统关键技术研 究 [J].网络新媒体技术,2012,1(06):20-26.

[2]王孝亮. 面向智能电网应用的电力大数据关键技术应用[J]. 工程技 术:全文版,2017,(02):189.

[3]秦晓波,霍立文,柴志成.面向大数据云存储系统的关键技术研究 [J]. 电脑迷, 2018,(06):68. 
质量造成影响。

2. 2 分段围堰法导流技术

在一些河床狭窄的环境下, 通常会对分段围堰法导流技术进行应用, 这样能够大幅度提高河床的下泄功能, 但是这项技术的应用, 经常会延长 施工工期, 因此, 一般需要对工程进行分段或分期处理。所谓分期处理, 主 要就是划分为若干个时期, 借助围堰将水中建筑物维护起来, 这样也能够 为后续施工提供便利条件。在河床下泄过程中, 泄水建筑物会存在缺口和 底孔，因此也会将分段围堰法导流技术分为缺口导流技术以及底孔导流技 术。实践过程中, 施工人员可结合施工现场的实际情况, 对合适的导流技术 进行选择 ${ }^{[4]}$ 。

\section{3坝体缺口导流设计}

在水利工程施工建设过程中, 混凝土坝体结构十分常见, 在遇到河 水汛期时, 水流量会迅速增大, 若以往的导流系统不能确保水利工程施 工项目的顺利进行, 那么通常会预留出一个缺口, 从而确保在河水汛期 时, 通过这一缺口将水排放出去。通过与混凝土施工的有效融合, 能够大 幅度提高信息排水量, 在汛期过后, 需要对结构进行重新的设计, 并进行 导流施工处理。在闸坝混凝土施工过程中, 在浇筑混凝土的前期阶段, 需 要做好测量、定位工作之后才能进行浇筑, 另外还要重点关注水泥和添 加剂的比例问题 ${ }^{[5]}$ 。

\section{3 水利工程施工中提高导流施工技术水平的有效建议}

3. 1 加大科技创新力度

随着现代科技的不断发展, 在水利工程施工过程中, 对于导流施工技 术的应用也要实现创新和进步, 以促进水利工程事业的可持续稳定发展。 当前, 我国水利工程事业发展尤为迅速, 在此过程中, 相关科研人员也要强 化对工程技术的研究和创新, 从而研究出更多的新型技术。传统的水利工 程施工技术很难满足当前的社工需求, 因此, 如果导流技术不能实现与时 俱进, 那么在今后的发展过程中, 也会很难满足工程建设目标。鉴于上述情 况, 在今后的水利工作施工中, 需要在确保导流施工技术合理科学的基础 上对其进行开发和钻研, 以促进其更好的发展, 从根本上提高工程建设质 量 $^{[6]}$ 。

\section{2 强化水利人才培养}

不管是任何行业的发展, 人才所发挥的优势都不可忽视, 而这也是提 高行业市场竞争力的重要因素。随着现代科技的不断发展, 对于水利工程 建设也提出更高要求, 目前, 国内水利工程行业市场竞争日趋激烈, 在此情 况下也对水利人才培养提出了新的要求。在水利工程企业中, 要加大对各
种优秀杰出人才的引进力度, 做好教育和培训工作。首先, 可对水利人才进 行对外扩招, 并通过校园招聘、网络传播等方式, 吸引更多的毕业生加入到 企业。其次, 对于新员工, 在其正式上岗之前, 企业要对其进行教育和培训, 使其掌握更多专业常识, 提高其专业技能, 以便于能够在今后的工作中得 心应手, 妥善做好自己的本职工作。最后, 企业还要建立一支优质的技术人 才团队, 这样才能为企业的健康稳定发展提供保障, 强化水利工程施工技 术创新。

3. 3对企业管理机制进行完善

水利工程施工不仅能够为企业发展带来效益, 同时也促进了国家经 济的健康稳定发展, 因此, 水利工程企业必须要建立起完善的内部管理 机制, 这将会对水利工程的效率和进展产生直接影响。实践过程中, 企业 可结合当前的发展状况, 对管理体系进行建立, 同时还要对施工过程中 的相关技术进行创新, 如果企业缺乏完善可行的内部管理机制, 便容易 使工程在运行过程中出现安全事故, 从而对整个水利工程事业造成不利 影响。在水利工程施工过程中导流技术至关重要, 对该技术进行创新, 可 大幅度提高工程效益, 而管理制度的建立则是实现上述目标的基础, 因 此必须要引起重视。

\section{4 结语}

综上所述, 本文主要对水利工程施工中导流施工技术的应用进行了分 析, 总之, 导流施工技术在水利工程施工中的合理应用, 不仅能够为施工创 建良好环境, 同时也能大幅度提高施工质量, 对于我国水利工程事业的长 久稳定发展很有帮助。

\section{[参考文献]}

[1]杨志梅.水利水电施工中施工导流和围堰技术的应用 [J].民营科 技,2018,(02):99.

[2]王丽清.导流技术在水利工程大坝施工中的应用浅析[J]. 黑龙江水 利科技,2017,45(11):157-159.

[3]白杨清.水利工程施工中导流施工技术的应用研究 [J].中小企业管 理与科技,2017,(22):142-143.

[4]穆秀英, 吴新.浅谈黄登水电站导流隧洞工程钢模台车费用分推 $[J]$. 水利建设与管理,2015,31(4):60-62.

[5]倐玉冬.浅谈水利灌溉区钢板桩围堰导流施工技术的应用[J].科学 技术创新,2017,(12):203.

[6]高原,刘付涛.浅谈水利水电施工对于施工导流和围堰技术的运用 [J].科技创新与应用,2017,(9):225。 